\title{
HABITAT USE BY NATIVE AND STOCKED TROUT (SALMO TRUTTA L.) IN TWO NORTHEAST STREAMS, PORTUGAL
}

\author{
A. TEIXEIRA (1), R.M.V. CORTES (2), D. OLIVEIRA (2)
}

(1) CIMO, Escola Superior Agrária de Bragança, Campus Sta Apolónia, Apart. 1172, 5301-855 Bragança, Portugal.

E-Mail: amilt@ipb.pt

(2) Universidade de Trás-os-Montes e Alto Douro, Dep. Florestal, Apart. 1013, 5001-911

Vila-Real, Portugal.

E-Mail: rcortes@utad.pt

Reçu le 3 novembre 2004

Accepté le 13 juin 2006

Received November 3, 2004

Accepted June 13, 2006

\begin{abstract}
Habitat use by stocked and native brown trout (Salmo trutta L.) was assessed in two headwater streams of North-eastern Portugal. Underwater observations were made during the summer season in three successive years to evaluate the effect of supplemental trout stocking. Multivariate analysis techniques applied to data sets on microhabitat use were exploited to identify the focal elevation (distance of fish from the bottom), total depth and cover as the variables that contribute most to the discrimination between stocked and native trout. Preference curves computed for native and stocked trout of the same age $\left(1^{+}\right)$, showed a distinct pattern in their ability to explore the available microhabitat resources. Stocked trout tended to occupy deeper pools (total depth $>100 \mathrm{~cm}$ vs. 60 $100 \mathrm{~cm}$ for native trout), holding higher focal elevations $(140-160 \mathrm{~cm} v \mathrm{~s} .<20 \mathrm{~cm}$ for native) with lower water column velocities $\left(<10 \mathrm{~cm} \cdot \mathrm{s}^{-1}\right.$ vs. $10-20 \mathrm{~cm} \cdot \mathrm{s}^{-1}$ for native) and no specific preference for cover. In contrast, native trout displayed a clear preference for microhabitats with coarse substrate (particle size $>22.5 \mathrm{~cm}$ ) and cover (combination of boulders and overhanging vegetation or undercut banks). Furthermore, a high poststocking movement of $80 \%$ hatchery-reared fish was verified just one month after their release, suggesting that stocking did not contribute to the sustainable populations in either stream, and is far from being an adequate management technique.
\end{abstract}

Key-words: Salmo trutta, snorkelling, restocking, microhabitat, preference curves.

\section{UTILISATION DE L'HABITAT PAR LA TRUITE COMMUNE (SALMO TRUTTA L.) SAUVAGE ET CELLE D'ÉLEVAGE, DANS DEUX RIVIÈRES DU NORD-EST DU PORTUGAL}

\section{RÉSUMÉ}

L'utilisation de l'habitat par la truite de repeuplement et par la truite commune (Salmo trutta) a été évaluée dans deux rivières du Nord-Est du Portugal. Des observations en plongée ont été faites en période estivale pendant trois années successives pour évaluer l'efficacité des repeuplements. Des techniques d'analyses multivariées appliquées à l'ensemble des données du microhabitat ont permis d'identifier la position 
focale (distance du poisson au lit de la rivière), la profondeur totale et les abris comme étant les variables contribuant le plus à la discrimination entre les truites natives et les truites de repeuplement. Les courbes de préférence des truites natives et de celles de repeuplement de même âge $\left(1^{+}\right)$ont montré des aptitudes distinctes d'exploitation de l'habitat disponible. Les truites de repeuplement ont tendance à occuper les zones plus profondes (profondeur totale $>100 \mathrm{~cm}$ vs. $60-100 \mathrm{~cm}$ pour les truites natives), à avoir une position focale supérieure $(140-160 \mathrm{~cm}$ vs. $<20 \mathrm{~cm}$ pour les natives), à préférer de plus faibles vitesses de courant dans la colonne d'eau $\left(<10 \mathrm{~cm} . \mathrm{s}^{-1} \mathrm{vs} .10-20 \mathrm{~cm} . \mathrm{s}^{-1}\right.$ pour les natives) et ne montrent pas de préférence spécifique pour les abris. Au contraire, les truites natives ont une nette préférence pour les microhabitats à granulométrie grossière (particules $>22.5 \mathrm{~cm}$ ) et les abris (combinaison de cailloux, végétation ripicole ou sous berges). Enfin, 80 \% des poissons d'élevage avaient migré un mois seulement après leur déversement, suggérant que le repeuplement n'ait pas contribué au développement des populations des deux rivières, et n'est donc pas une technique de gestion adéquate.

Mots-clés : Salmo trutta, observations en plongée, repeuplement, microhabitat, courbes de préférence.

\section{INTRODUCTION}

Stocking, transfer and introduction of fish are management tools commonly used by fishery owners or managers to enhance their stocks (COWX, 1998). Hatchery-reared fish have been used to introduce species into natural or recently created systems (e.g. reservoirs), to compensate for the absence or failure of natural reproduction, to introduce or maintain recreational and commercial fisheries or to conserve species with a high extinction risk (WHITE et al., 1995; WELCOMME, 1998). However, limitations in space and time associated with high effective costs have resulted many times in the low success rate of these activities. Furthermore, several studies have reported negative consequences of stocking such as the spread of parasites and diseases (MOFFIT et al., 1998), an increase of competitive interactions (NICKELSON et al., 1986; McMICHAEL and PEARSONS, 1997), and, more recently, genetic introgression (BLANCO et al., 1998; CAGIGAS et al., 1999; ALMODÓVAR et al., 2001).

Appropriate fishery management should be closely related to the knowledge of the ecological requirements of fish stocks, impacts on community structure and effects of human activities. WHITE et al. (1995) claimed that there should be post-stocking monitoring programs in order to estimate the fate of stocked fish (survival, body growth, reproductive success), the effects on native fish populations (hybridisation, competition, predation) and, ultimately, the social and economic benefits. For APRAHAMIAN et al. (2003) the greatest benefit from a stocking program is obtained when it is specifically designed for each type of habitat. However, in this case more precise information is required, namely the one related to habitat use. It is known that salmonids tend to select habitats that provide several benefits related with swimming costs, prey capture success, predation risk or adverse environmental conditions (EVEREST and CHAPMAN, 1972; FAUSCH, 1984; HUGHES and DILL, 1990). However, the introduction of stocked fish can induce the displacement and the exclusion of native fish (LARSON and MOORE, 1985; FAUSCH, 1988; McMICHAEL et al., 1999). Therefore, many supplemental stocking programs have had negative effects on the survival and growth of native populations (MCMICHAEL and PEARSONS, 1997; PEERY and BJORNN, 2000) with severe consequences on fish productivity of aquatic systems (NEHLSEN et al., 1991).

The preservation of wild gene pools of native stocks of brown trout (Salmo trutta L.) is currently a high concern in Europe. A large part of the genetic diversity of brown trout is located in southern European countries (GARCÍA-MARIN et al., 1999; SANZ et al., 2000). Moreover, Iberian brown trout populations display high genetic differentiation with 
four major haplotype groups (MACHORDOM et al., 2000; SUÁREZ et al., 2001). Genetic investigations have shown that this variability is present in the Douro basin where this study was conducted, which also presents a unique mitochondrial haplotype. However, in this catchment $25 \%$ of the populations showed introgression by genes of hatchery origin, demonstrating the extent of the problem (ALMODÓVAR et al., 2001).

Supplemental stocking of brown trout is still a regularly used strategy to improve fisheries in upland streams of Northern and Central Portugal, but there are few studies evaluating the efficiency of these stocking programs. The present study took place in two streams of the Douro river catchment. The objective was to investigate intra-specific interactions for habitat use between native and stocked trout. We particularly assessed the overlap extent of microhabitat preference.

\section{MATERIAL AND METHODS}

The study was conducted in the Baceiro and Sabor streams, two third-order tributaries of the Douro River, located in the Montesinho Natural Park, North-eastern Portugal. In each stream two reaches were selected (defined as upper and lower ones), approximately $2.5 \mathrm{~km}$ in length and $4 \mathrm{~km}$ apart. Both drainage basins enjoy reduced human pressure contributing to a low impact on aquatic systems. Schist dominates the geological substrate, but small areas of granites and serpentine rocks are also present. The water proved to be poorly buffered (conductivity $<70 \mu \mathrm{S} . \mathrm{cm}^{-1}$, alkalinity $<25 \mathrm{mg} \mathrm{HCO}_{3}^{-}$

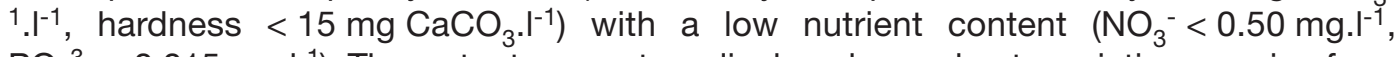
$\mathrm{PO}_{4}^{3-}<0.015 \mathrm{mg}^{3-1}$ ). The water temperature displayed a moderate variation, ranging from $4{ }^{\circ} \mathrm{C}$ in winter to $20^{\circ} \mathrm{C}$ in summer. The altitude of the stream reaches ranged between $725-850 \mathrm{~m}$ in the Baceiro stream and between 600-775 $\mathrm{m}$ in the Sabor stream. The mean

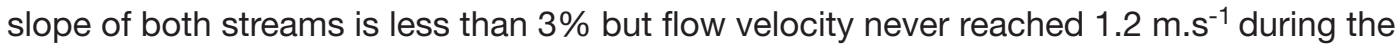
study periods. The stream banks are covered by dense corridors of riparian vegetation, dominated by alder (Alnus glutinosa). Both streams are structured as a succession of relatively deep pools with medium size substrate (gravel and stones) and small shallow riffles with rough substrate (mainly boulders). Primary production is usually insignificant and streams are energetically dependent on allochthonous inputs of organic matter. The upper reaches are characterized by the exclusive presence of trout populations. Trout cohabit with cyprinids in the lower reaches of both rivers.

Stocking was carried out during the summer in three successive years (2000 to 2002), with conventional hatchery-reared trout of age $1^{+}$(size range $=14.0-26.0 \mathrm{~cm}$ TL; mean $\pm \mathrm{SD}=20.3 \pm 2.7 \mathrm{~cm} ; n=1,300$ per year in both streams). Prior to release, all trout were marked with VIE - Visible Implant Elastomer (Northwest Marine Technology@) and unique marks for each group of individuals were defined (combination of body locations - adipose fin and post-ocular tissue, with four different colours), which facilitated later identification of the habitat units where the fish were released. The fish were maintained in low-density raceways for ten days to recover from stress and to scab over the marked tissues. In the first week of August the trout were transported to the streams in tanks with artificial $\mathrm{O}_{2}$ and distributed in several habitat units (scatter-spot technique) along the designated four reaches.

The habitats within each sampling reach were classified according to BISSON et al. (1982) into discrete units of slow flowing-pools, characterized by maximum depth $>0.75 \mathrm{~cm}$ and maximum water velocity $<0.20 \mathrm{~m} . \mathrm{s}^{-1}$, and fast flowing-riffles/runs with a maximum depth $<0.75 \mathrm{~cm}$ and maximum water velocity $>0.20 \mathrm{~m} . \mathrm{s}^{-1}$. In each unit the following variables were measured: length, bankfull and mean wetted width, maximum and mean depth, substrate composition (\% fine and coarse particles), available refuge (\% and type undercut banks, boulders), presence (ordinal scale) of particulate organic matter (POM) and large woody debris (LWD), species number of aquatic macrophytes and riparian vegetation, 
overhanging vegetation and bank stability (measured as percentage). The presence of vegetation and a well-developed root system that prevent erosion were considered signs of stable banks. Microhabitat availability surveys were made before snorkelling observations, following a stratified randomisation protocol used in each stream reach, with the habitat units selected proportionally to the pool/riffle ratio. Transects (starting point randomly chosen) were made perpendicular to the stream, with intervals of $5 \mathrm{~m}$ throughout each habitat unit. Point measurements were made at $0.5 \mathrm{~m}$ intervals across each transect for the variables of total depth, surface and mean water column velocity, substrate composition and cover. Substrate composition was classified according to a modified WENTWORTH scale, adopting the following categories: 1) organic detritus; 2) $<0.062 \mathrm{~mm}$; 3) $0.062 \mathrm{~mm}$ $2.0 \mathrm{~cm}$; 4) $2.1-4.0 \mathrm{~cm}$; 5) $4.1-7.5 \mathrm{~cm}$; 6) $7.6-15 \mathrm{~cm}$; 7) $15.1-22.5 \mathrm{~cm}$; 8) $22.6-60 \mathrm{~cm}$; 9) $>60 \mathrm{~cm} ; 10$ ) bedrock. A two-digit substrate index was used to define the dominant (first digit) and the subdominant component (second digit) of substrate. Cover was determined by fourteen categories expressing refuge availability for fish, adapted from the BOVEE classification (BOVEE, 1982). Total depth was measured directly with a stick meter. Finally, velocities $\left(\mathrm{m}^{-1} \mathrm{~s}^{-1}\right)$ were measured over a 30 second period with a VALEPORT electronic flowmeter. Velocity at 0.6 of total depth was considered as the mean water column velocity when the depth was less than $0.75 \mathrm{~m}$ (BOVEE and MILHOUS, 1978). At deeper points the readings were averaged at 0.2 and 0.8 of total depth.

Snorkelling observations were made before and after the restocking experiments of each year (last week of July and third week of August respectively) to assess microhabitat use by: 1) native trout populations and 2) sympatric native and stocked trout populations of upper and lower reaches in the Baceiro and Sabor streams. A total of 48 field surveys, 158 habitat units (randomly selected) and 4,653 trout (1,437 before restocking; 1,733 native and 1,483 stocked after) were sampled in all years and study reaches. The shallowest riffles were not surveyed because snorkelling was not possible, but they did not exceed $20 \%$ of the wetted area. Each survey was made during daylight hours (9.00-18.00) to ensure good underwater visibility, between $5 \mathrm{~m}$ in shaded areas and $>6 \mathrm{~m}$ in open areas. Before data collection specific training was undertaken in order to classify correctly the stocked and native trout. Several characteristics, such as the presence of the VIE elastomer, body colour (uniform and grey), pectoral fins (smaller) and behaviour, resulted in an easy identification of stocked fish. The snorkeller moved in an upstream direction and in a zigzag fashion to randomise any bias associated with near-shore or offshore observations. Once an undisturbed fish (only considered when it maintained position for at least 2 min.) was located, the snorkeller registered the TL- total length (estimated to the nearest $\mathrm{cm}$ through comparison with substrate particles) and the trout identification (stocked vs. native). Then, each fish position was marked with a numbered lead-weighted float (surface and focal position identified) and, after the entire habitat unit was snorkelled, the measurements were made by another field crew for the following variables: 1 ) focal velocity (velocity in the holding fish position); 2) mean water column velocity; 3) velocity at surface; 4) focal elevation (distance from bottom to fish's snout); 5) total depth; 6) substrate composition (0.25 $\times 0.25 \mathrm{~m}$ ) in a vertical line below the fish; and 7) cover (objects that could provide shelter for, at least, $50 \%$ of the fish's body) based on the BOVEE classification (BOVEE, 1982). Finally, in order to estimate the displacement of the released hatchery fish, electrofishing surveys (HANS GRASSL DC, 300-600 V, 1,5-2 A) were made, in a single passage, along all the four stream reaches, one and three months after the hatchery-reared trout release.

A direct ordination technique, the Canonical Correspondence Analysis - (CCA) was performed with the CANOCO package (TER BRAAK and SMILAUER, 1998) to examine the links between the structure of trout populations (size classes defined as $<7 \mathrm{~cm}$ and by each $2 \mathrm{~cm}$ groups, with log transformation of the abundance) and habitat variables. To explain the spatial distribution of the trout population, five Partial Canonical Correspondence Analysis (PCCA) runs were performed to calculate the contribution of the distinct groups of habitat variables. A forward stepwise discriminant function analysis (DFA) was further 
used to detect the physical variables (including fish position in the water column and microhabitat variables) that better discriminate between specific trout groups, defined as the hatchery-reared trout (S) and the following size classes of native trout: $A$ ) $<10.0 \mathrm{~cm}$; B) $10.1-15.0 \mathrm{~cm}$; C) $15.1-20.0 \mathrm{~cm}$; D) $>20.0 \mathrm{~cm}$. For native trout of the studied streams, these size classes roughly correspond to age classes of $0^{+}, 1^{+}, 2^{+}$and $\geq 3^{+}$(CORTES et al., 1996). To assess the impact of the stocked trout on the microhabitat's use by the native trout an additional DFA was made using the data concerning the habitat use of the native trout prior to stocking. DFA analyses were made considering all underwater observation data for the three study years. Non-parametric MANN-WHITNEY $U$ tests were performed to detect statistical differences in habitat use by native and stocked trout. The KRUSKALLWALLIS $\mathrm{H}$ test was used as a nonparametric analysis of variance to detect differences in habitat use between the various sampling years. Preference curves, respecting cover, dominant substrate, total depth, focal elevation, and water column and focal velocities, were established for the two considered trout populations. The preference was corrected according to habitat availability by calculating for each class of a given variable the use/ availability proportion followed by standardization in order to obtain a range from 0.0 (unsuitable) to 1.0 (optimal) (BALTZ et al., 1991). These curves were fitted to the data using polynomial regressions and the best model was selected. All statistical analyses were performed using the STATISTICA 7.0 package (STATSOFT, 2004).

\section{RESULTS}

The majority of hatchery-reared trout released in both streams showed, for all years, a high post-stocking movement since the number of stocked trout recaptured with electrofishing in the study reaches was very low, ranging from $10-20 \%$ after one month and reaching less than $5 \%$ after three months. It was noted that fish tended to remain aggregated for some days in precisely the same habitat unit where they had been released but afterward most of them gradually moved, in mainly the downstream direction.

The relative contribution of each group of environmental variables for the native trout distribution was determined after the PCCA analysis shown in Table I. We may conclude that there is a remarkably low contribution of the variables associated with the riverbank characteristics when compared to the in-stream factors. It is also clear that a high proportion of the variance remains unexplained. Figure 1 presents the biplot of samples and variables for the first two axes of the CCA, which present eigenvalues of 0.161 and 0.020 respectively for the first and second axes. This diagram shows differences in habitat preferences by YOY (individuals $<10 \mathrm{~cm}$ ) relatively to the adults. The first axis are more dependent on the available refuges provided by coarse materials $(>15 \mathrm{~cm})$ combined with the available canopy located in fast flowing reaches, whereas the second axis favour the refuges provided by the presence of undercut banks and the LWD deposited in wider and deeper pools.

DFA results, taking into account all years and the five predetermined groups (stocked, and four different size classes of native trout), showed that distinct groups could be separated primarily by focal elevation and, to a lesser extent, by total depth, focal velocity and microhabitat cover variables (Table II). The variance explained by the first three statistically significant ( $P<0.001$ ) functions (canonical roots) was $99.8 \%$ relative to all the roots. It is also important to mention that $84.2 \%$ of the observations on stocked trout were correctly classified, in contrast with the lower discriminant ability for the upper size classes of native trout. Comparatively, the DFA executed with the data prior to stocking, showed that focal elevation was insignificant. In contrast total depth, cover and focal velocity were the most important microhabitat variables justifying the separation between all size classes of native trout (Table II). A higher discriminatory power was detected for the first canonical root (discriminant function), which explained $85.7 \%$ of the variance relative to all the roots. However, this analysis classified correctly a lower number of observations (43.9\%) because the behaviour of native trout was similar for the different size classes, except for the YOY fish. 
Table I

Proportion of the Explained variance obtained by Partial Canonical Correspondence Analysis (PCCA) of the environmental variables linked to habitat use by trout and grouped in in-stream and corridor variables. Symbols - h max: maximal depth; POM: particulate organic matter; \% fines: percentage of fine materials $(<15 \mathrm{~cm})$; Stability: percentage of bank stability; Overhanging vegetation: \% canopy from riparian vegetation; Riparian: number of riparian tree species present Macrophytes: number of aquatic macrophyte species; LWD: large woody debris; Bankfull: bankfull width R/P type of habitat unit (riffle or pool); \% Refuge: percentage of coarse materials $(>15 \mathrm{~cm}$ ); Refuge type: Dominant refuge (undercut banks or boulders). $W^{*} h$ and $L^{*} W$ are new variables to express the interaction of mean width and mean depth of habitat unit and of its length and mean width.

Tableau I

Proportion de variation expliquée évaluée par Analyse Canonique Partielle des Correspondances (PCCA) des variables environnementales relatives à l'habitat utilisé par les truites et regroupées en variables de couloir fluvial et de canal. Symboles - $\mathrm{h}$ max : profondeur maximale ; POM : matière organique particulaire ; $\%$ fines: pourcentage de matériaux fins $(<15 \mathrm{~cm})$; Stability : pourcentage de stabilité des bancs ; Overhanging vegetation : pourcentage de couverture végétale riparienne ; Riparian nombre d'espèces arboricoles ripariennes ; Macrophytes : nombre d'espèces de macrophylles aquatiques; LWD: large débris ligneux; Bankfull : largeur totale de la rivière ; R/P : type d'habitat (radier ou profond); $\%$ Refuge : pourcentage de matériaux grossiers $(>15 \mathrm{~cm})$; Refuge type : refuge dominant (bancs dénudés ou cailloux). $W^{*} h$ et $L^{*} W$ sont de nouvelles variables exprimant l'interaction entre la largeur moyenne et la profondeur moyenne de l'habitat et entre sa longueur et sa largeur moyenne.

\begin{tabular}{|c|c|c|c|}
\hline $\begin{array}{l}\text { Source of } \\
\text { variation }\end{array}$ & $\begin{array}{c}\text { Explained variance } \\
\text { (total inertia 1.109) }\end{array}$ & Variables included & Co-variables \\
\hline All variables & $21.46 \%$ & $\begin{array}{l}\text { Instream + fluvial } \\
\text { corridor }\end{array}$ & \\
\hline $\begin{array}{l}\text { In-stream } \\
\text { variables }\end{array}$ & $16.3 \%$ & $\begin{array}{l}\mathrm{P} / \mathrm{R}, \mathrm{h} \text { max, refuge type, } \\
\% \text { refuge, macrophyte } \\
\text { spp, \% fines, POM, } \\
\text { LWD, I*w, } \mathrm{w}^{*} \mathrm{~h}\end{array}$ & $\begin{array}{l}\text { Overhanging vegetation, } \\
\text { bank stability, riparian } \\
\text { spp, bankfull width }\end{array}$ \\
\hline $\begin{array}{l}\text { Fluvial corridor } \\
\text { variables }\end{array}$ & $3.9 \%$ & $\begin{array}{l}\text { Overhanging vegetation, } \\
\text { bank stability, riparian } \\
\text { spp, bankfull width }\end{array}$ & $\begin{array}{l}\mathrm{R} / \mathrm{P}, \mathrm{h} \text { max, refuge type, } \\
\% \text { refuge, macrophyte } \\
\text { spp, \% fines, POM, } \\
\text { LWD, I*w, w*h }\end{array}$ \\
\hline Shared & $2.7 \%$ & & \\
\hline Unexplained & $78.54 \%$ & & \\
\hline
\end{tabular}




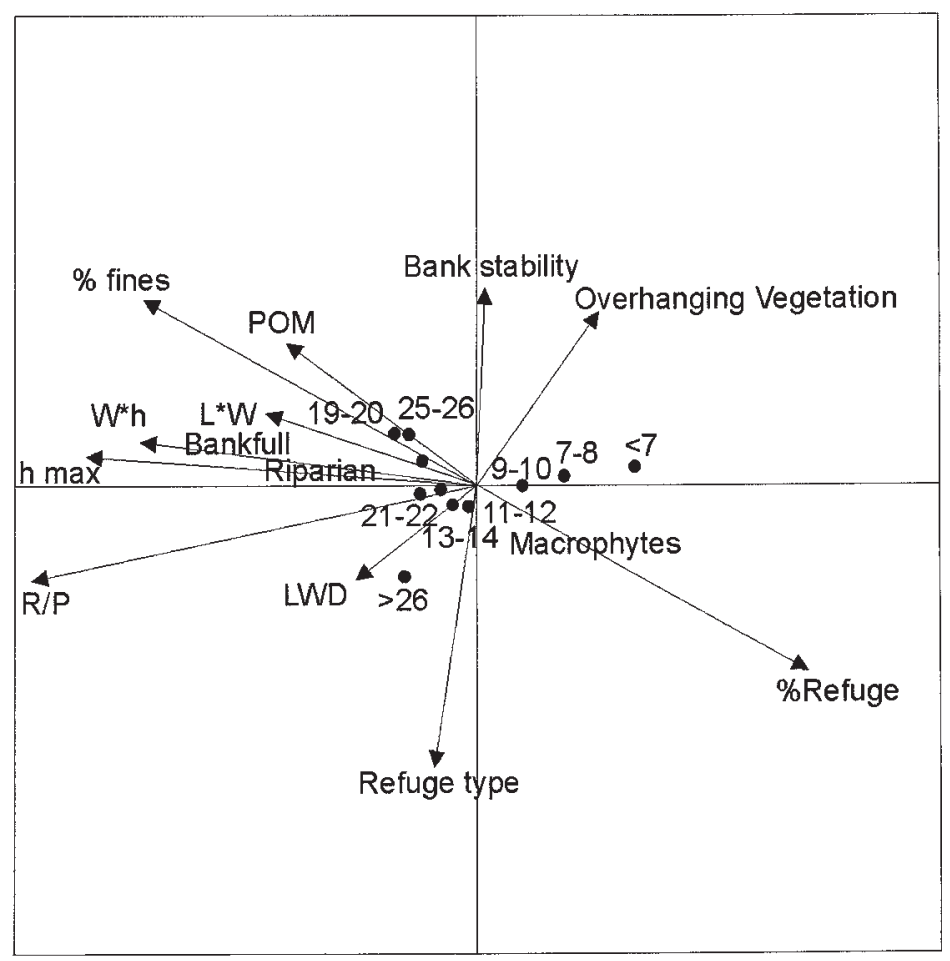

Figure 1

CCA ordination diagram - position of samples (size classes of native trout) and variables (in-stream and corridor variables) for the two first axes. Arrows represent the environmental variables and dots the size classes of trout: $A$ ) arrows $-W^{*} h$ : mean width * mean depth of habitat unit; L*W: length*mean width; $h$ max: maximal depth; POM: particulate organic matter; $\%$ fines: percentage of fine materials $(<15 \mathrm{~cm})$; Bank stability: percentage of bank stability; Overhanging vegetation: $\%$ canopy from riparian vegetation; Riparian: number of riparian tree species present; Macrophytes: number of aquatic macrophyte species; LWD: large woody debris; Bankfull: bankfull width; R/P: type of habitat unit-riffle or pool; \% Refuge: percentage of coarse materials $(>15 \mathrm{~cm}$ ); Refuge type: Dominant refuge (undercut banks or boulders). B) Points: size classes of trout (e.g. 7-8: trout 7 or $8 \mathrm{~cm}$ long). The length of the arrow is a measure of the importance of the environmental variable and the arrowhead points at the direction of increasing influence.

\section{Figure 1}

CCA diagramme d'ordination position des échantillons (classes de taille des truites natives) et des variables (dans le cours d'eau et dans les radiers) pour les deux premiers axes. Les flèches représentent les variables environnementales et les points des classes de taille des truites: $A$ ) flèches $W^{*} h$ : largeur moyenne * profondeur moyenne de l'habitat; $L * W$ : longueur * largueur moyenne; $h$ max : profondeur maximale ; POM : matière organique particulaire ; \% fines : pourcentage de matériaux fins $(<15 \mathrm{~cm})$; Bank Stability : pourcentage de stabilité des bancs; Overhanging vegetation : pourcentage de couverture par la végétation riparienne; Riparian: nombre d'espèces d'espèces arboricoles ripariennes présentes; Macrophytes : nombre d'espèces de macrophylles aquatiques; LWD : large débris ligneux ; Bankfull : largeur totale de la rivière ; R/P : type d'habitat (radier ou profond) ; $\%$ Refuge : pourcentage de matériaux grossiers $(>15 \mathrm{~cm})$; Refuge type : refuge dominant (bancs dénudés ou cailloux). B) Points : classes de taille des truites (ex. 7-8: truites de 7 et $8 \mathrm{~cm}$ de long). La longueur de la flèche reflète l'importance de la variable environnementale et la pointe de la flèche le sens du gradient d'influence. 
Table II

Discriminant function analysis after and before (data between parentheses) the stocked trout release - Wilks' Lambda of each variable and the Classification Functions according to different size classes for native (Group A-D) and stocked (Group S) trout. Variables are listed in the order in which they were included in forward stepwise analysis after stocked trout release.

\section{Tableau II}

Analyse fonctionnelle discriminante avant et après (données entre parenthèses) déversement des truites de repeuplement - Wilks' Lambda de chaque variable et de chaque classification fonctionnelle d'accord avec les différentes classes de taille pour les truites natives (groupe A-D) et les truites de repeuplement (groupe S). Les variables sont présentées dans l'ordre de leur inclusion dans la régression pas à pas descendante faite sur les données postérieures au déversement des truites de repeuplement.

\begin{tabular}{|c|c|c|c|c|c|c|}
\hline \multicolumn{7}{|c|}{ Discriminant Function Analyses } \\
\hline \multirow{2}{*}{$\begin{array}{c}\mathrm{n}_{\text {after stocking }}=3,216 \\
\mathrm{n}_{\text {before stocking }}=1,437\end{array}$} & \multirow{2}{*}{$\begin{array}{c}\text { Wilks' } \\
\text { Lambda }\end{array}$} & \multicolumn{5}{|c|}{ Classification Functions } \\
\hline & & $\begin{array}{c}\text { Group A } \\
p=0.157 \\
(p=0.342)\end{array}$ & $\begin{array}{c}\text { Group B } \\
p=0.205 \\
(p=0.270)\end{array}$ & $\begin{array}{c}\text { Group C } \\
p=0.122 \\
(p=0.318)\end{array}$ & $\begin{array}{c}\text { Group D } \\
p=0.054 \\
(p=0.070)\end{array}$ & $\begin{array}{l}\text { Group S } \\
\mathrm{p}=0.461\end{array}$ \\
\hline Focal elevation & $\begin{array}{l}0.782 \\
(0.882)\end{array}$ & $\begin{array}{l}-0.371 \\
(-0.027)\end{array}$ & $\begin{array}{r}-0.576 \\
(0.083)\end{array}$ & $\begin{array}{l}-0.829 \\
(-0.008)\end{array}$ & $\begin{array}{l}-0.732 \\
(-0.148)\end{array}$ & 0.687 \\
\hline Total depth & $\begin{array}{l}0.684 \\
(0.941)\end{array}$ & $\begin{array}{l}-0.550 \\
(-0.410)\end{array}$ & $\begin{array}{l}0.004 \\
(0.195)\end{array}$ & $\begin{array}{l}0.516 \\
(0.165)\end{array}$ & $\begin{array}{l}0.393 \\
(0.504)\end{array}$ & 0.004 \\
\hline Focal velocity & $\begin{array}{l}0.656 \\
(0.897)\end{array}$ & $\begin{array}{c}0.372 \\
(0.271)\end{array}$ & $\begin{array}{l}-0.242 \\
(-0.216)\end{array}$ & $\begin{array}{r}-0.052 \\
(0.018)\end{array}$ & $\begin{array}{c}0.038 \\
(-0.581)\end{array}$ & -0.010 \\
\hline Cover & $\begin{array}{l}0.662 \\
(0.887)\end{array}$ & $\begin{array}{c}0.116 \\
(-0.105)\end{array}$ & $\begin{array}{c}0.019 \\
(-0.025)\end{array}$ & $\begin{array}{l}0.298 \\
(0.080)\end{array}$ & $\begin{array}{l}0.387 \\
(0.251)\end{array}$ & -0.173 \\
\hline Water column velocity & $\begin{array}{l}0.655 \\
(0.891)\end{array}$ & $\begin{array}{c}0.186 \\
(-0.200)\end{array}$ & $\begin{array}{c}0.265 \\
(0.201)\end{array}$ & $\begin{array}{c}0.023 \\
(0.201)\end{array}$ & $\begin{array}{r}-0.150 \\
(0.444)\end{array}$ & -0.169 \\
\hline Dominant substrate & $\begin{array}{l}0.653 \\
(0.885)\end{array}$ & $\begin{array}{l}-0.160 \\
(-0.062)\end{array}$ & $\begin{array}{r}-0.112 \\
(0.099)\end{array}$ & $\begin{array}{l}-0.035 \\
(-0.059)\end{array}$ & $\begin{array}{r}-0.029 \\
(0.194)\end{array}$ & 0.116 \\
\hline Subdominant substrate & $\begin{array}{c}0.652 \\
(0.885)\end{array}$ & $\begin{array}{r}-0.212 \\
(0.021)\end{array}$ & $\begin{array}{r}-0.019 \\
(0.083)\end{array}$ & $\begin{array}{l}-0.007 \\
(-0.123)\end{array}$ & $\begin{array}{c}0.041 \\
(0.132)\end{array}$ & 0.078 \\
\hline Constant & - & $\begin{array}{l}-2.287 \\
(-1.172)\end{array}$ & $\begin{array}{l}-1.731 \\
(-1.349)\end{array}$ & $\begin{array}{l}-2.372 \\
(-1.168)\end{array}$ & $\begin{array}{l}-3.164 \\
(-2.883)\end{array}$ & -1.001 \\
\hline $\begin{array}{l}\text { Predicted classifications } \\
\text { (\% Corrected Cases) }\end{array}$ & - & $\begin{array}{l}25 \\
(74)\end{array}$ & $\begin{array}{l}24 \\
(19)\end{array}$ & $\begin{array}{c}14 \\
(42)\end{array}$ & $\begin{array}{c}0 \\
(0)\end{array}$ & 84 \\
\hline
\end{tabular}


No significant differences ( $P>0.05$, MANN-WHITNEY $U$ Test) were detected in microhabitat availability between years for both streams. However, a $U$ test detected highly significant differences $(P<0.001)$ between the upper and lower reaches of the two streams, for the following variables: total depth, cover and water column velocity. Additionally, in the Baceiro stream significant differences were also found for the dominant substrate $(P<0.001)$. Comparative analyses on microhabitat use between stocked and native trout of the same age $\left(1^{+}\right)$verified the existence of significant differences $(P<0.05$, $U$ test) for the variables of focal elevation, total depth and cover in all years and stream reaches. The comparison between stocked and the other size classes of native trout ( $A, C$ and $D$ classes) also revealed significant differences for the majority of variables analysed $(P<0.05, U$ test). But, the most significant differences $(P<0.001, U$ test $)$ were again identified when tests were made comparing habitat use by stocked and YOY wild trout. This class also showed highly significant differences not only for the domestic trout but also for the remaining size classes of native trout in all reaches and years $(P<0.001$, $\mathrm{U}$ test). The comparisons between before and after stocking periods found no significant differences $(P>0.05, U$ Test) for the adult native trout ( $C$ and $D$ classes) considering all the microhabitat variables defined. However, significant differences were detected $(P<0.05$, $U$ Test) for dominant substrate and cover (only in the Baceiro stream) related to native $B$ class and for total depth (Baceiro stream) and water column velocity with respect to YOY trout.

Significant differences between years $(P<0.001$, KRUSKAL-WALLIS, $H$ test) were registered for all the variables, characterizing the microhabitat used by stocked trout in all reaches. On the other hand, native trout, analysed by year classes, did not exhibit significant variation in microhabitat use in the three years considered ( $P>0.001, \mathrm{H}$ test). The exception was substrate use by YOY fish.

From observation of the preference curves performed for the Baceiro and Sabor streams (Fig. 2), there appears to be a distinct microhabitat use by stocked and native trout of the same age $\left(1^{+}\right)$, which did not alter substantially the pattern displayed before and after stocking. Stocked fish were normally found in the deeper zones (total depth $>100 \mathrm{~cm}$ ) of each habitat unit surveyed and held positions more distant from the streambed (focal elevation $=140-160 \mathrm{~cm}$ ). These trout showed preference for a bedrock substrate (code 10) and organic detritus deposition (code 1, only in Sabor stream) but not for a specific type of cover. The probability values for water column and focal velocities uses revealed their tendency to avoid riffles. In comparison, native trout displayed an evident preference for focal elevations near the stream bottom $(<20 \mathrm{~cm})$ and a coarser substrate (particle size $>22.5 \mathrm{~cm}$, codes 8 and 9). Boulders in conjunction with overhanging vegetation or undercut banks (cover codes 11 and 12) were the microhabitat cover preferred by the native fish. No substantial differences were detected in relation to focal velocity, but native trout showed a greater preference for superior water column velocity $\left(20-30 \mathrm{~cm} . \mathrm{s}^{-1}\right)$ than stocked fish. A similar pattern between stocked and native trout was observed in the different study years.

\section{DISCUSSION}

Supplemental stocking procedures, like the ones that took place in the Sabor and Baceiro streams, have been questioned as a management tool since they make no positive contribution to overcoming depletion of trout populations in a particular river. In fact, there was no significant increase of trout densities in the study area over a long-term period. Given the movement exhibited by the captured trout it is possible that most of the individuals travelled long distances in a downstream direction just one month after their release. The post-stocking movement of salmonids has already been reported in several studies (CRESSWELL, 1981; MORING, 1993; JONSSON et al., 1999), although contradictory results have also been obtained (HEGGENES, 1988; NASLUND, 1998). 


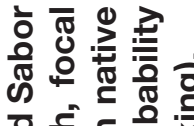

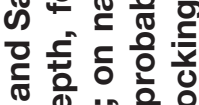

웡

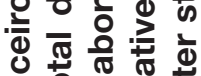

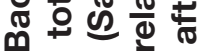

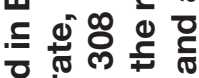

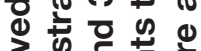

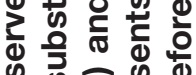

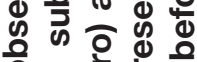

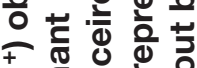

₹.

\% है응

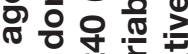

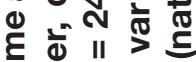

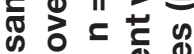

ธ웡

声茯。

온 형웡 웡

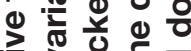

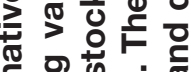

을

둘

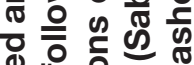

西

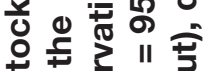

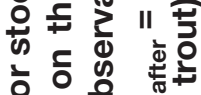

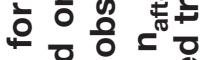

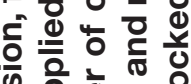

西

0

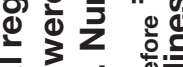

西

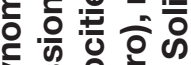

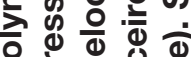

西

오워 뜽 뜬

क人 응

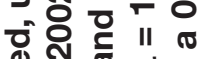

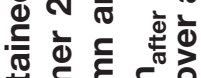

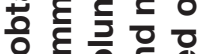

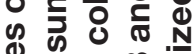

政

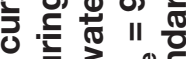

응 3

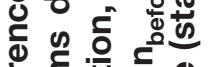

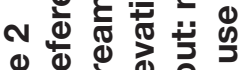

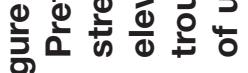

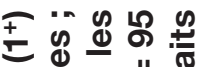

๑) 등

ช

를 ڤ

¿

응 은

乡

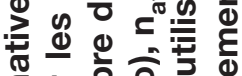

늑을은 흥

ต ज ह 웡 흥

我

드워웡

ह

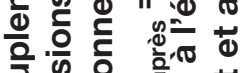

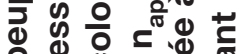

읐 잉

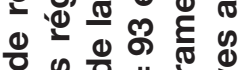

भ

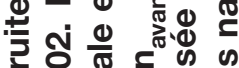

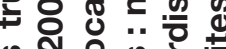

o

넌

产

롱 ๘

언 는

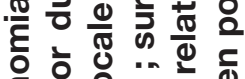

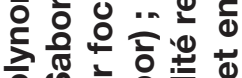

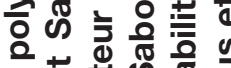

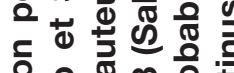

음 을 응 응 등

๘

히 ๘

은

政密

o. 곤 뜽

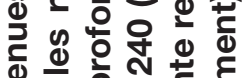

过

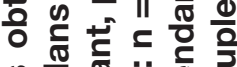

o 0 \%

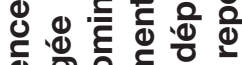

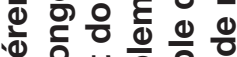

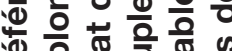

드 홍 은 는

๘

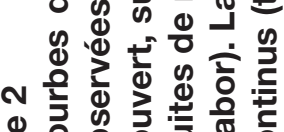

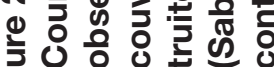
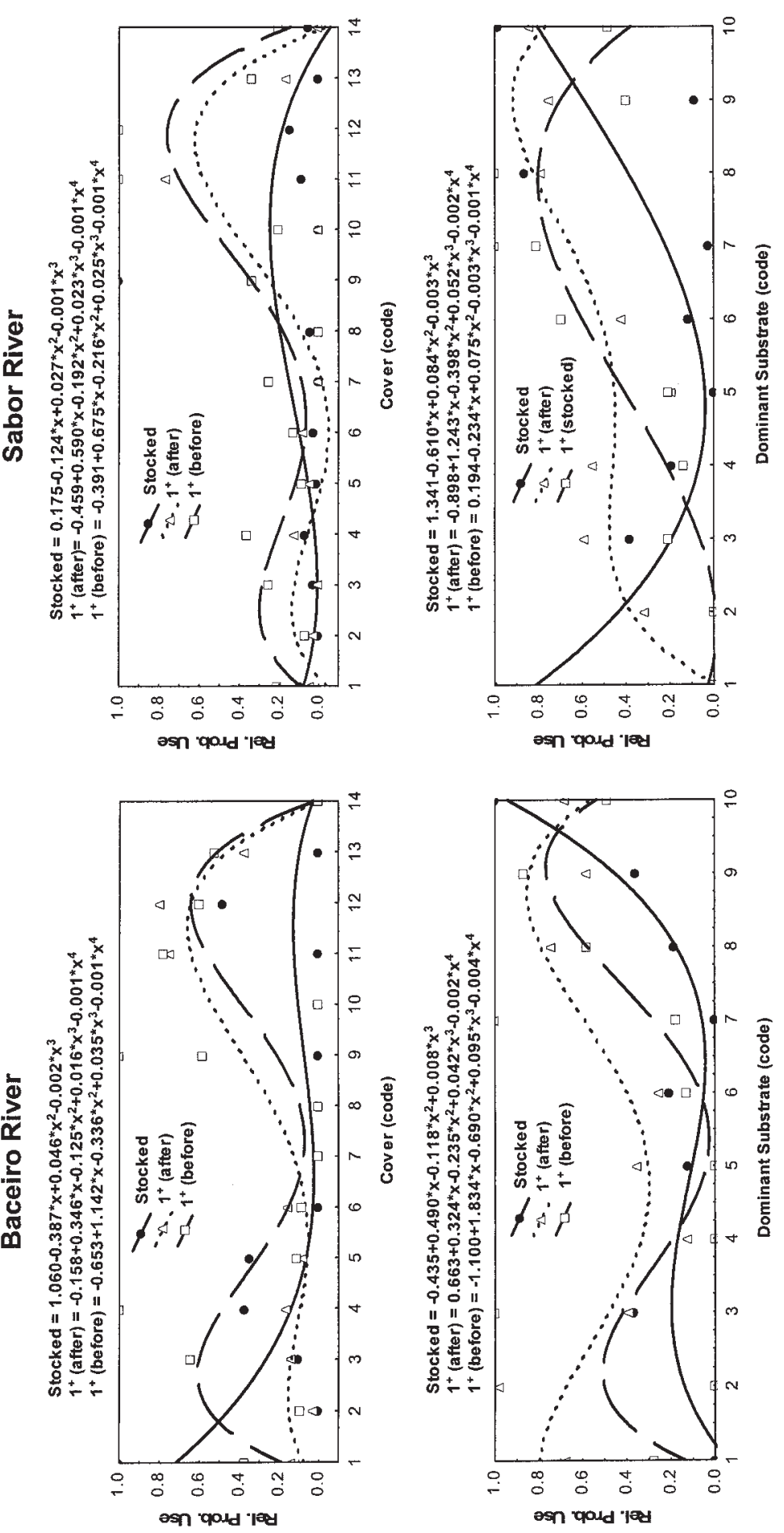

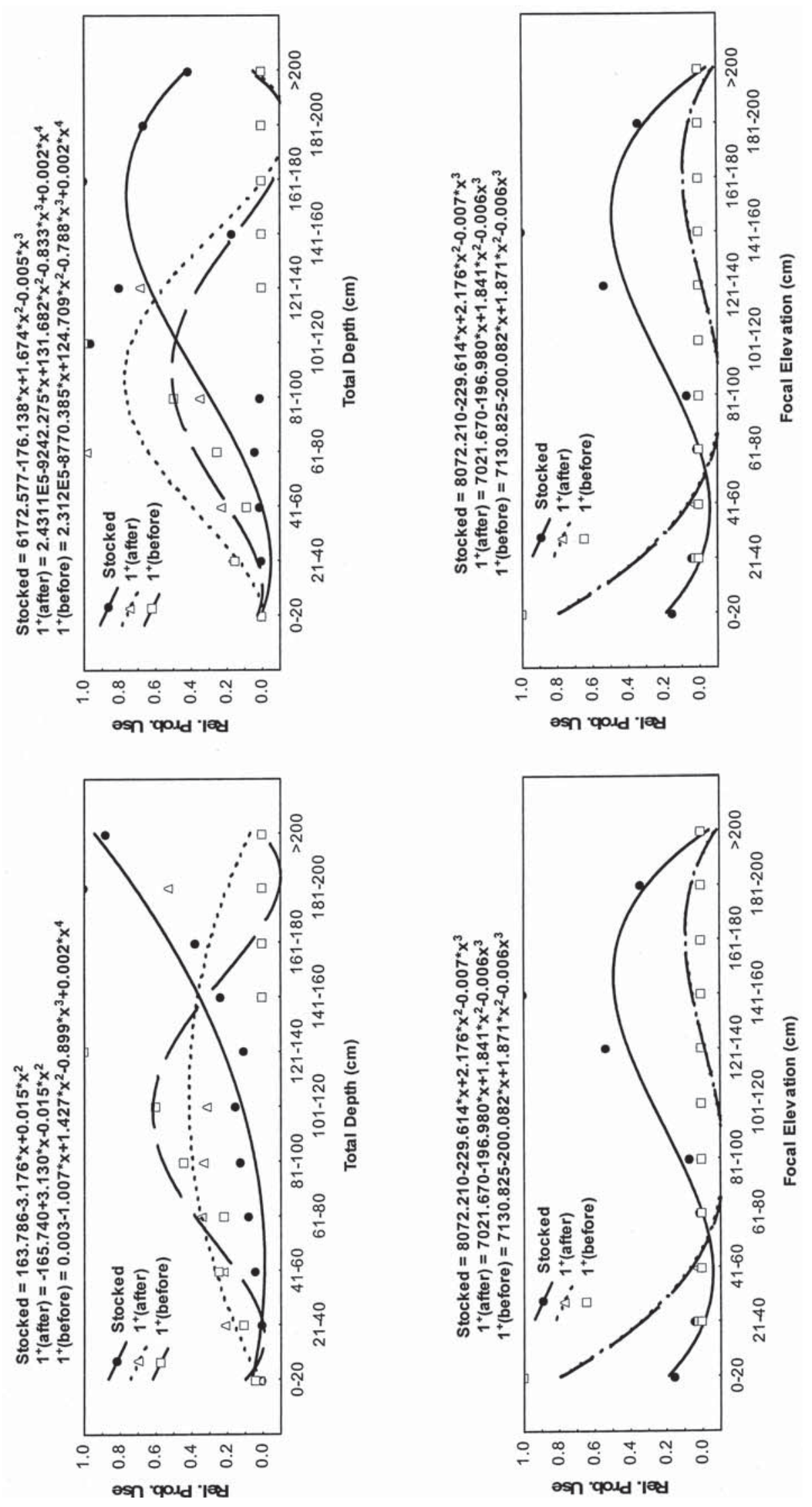

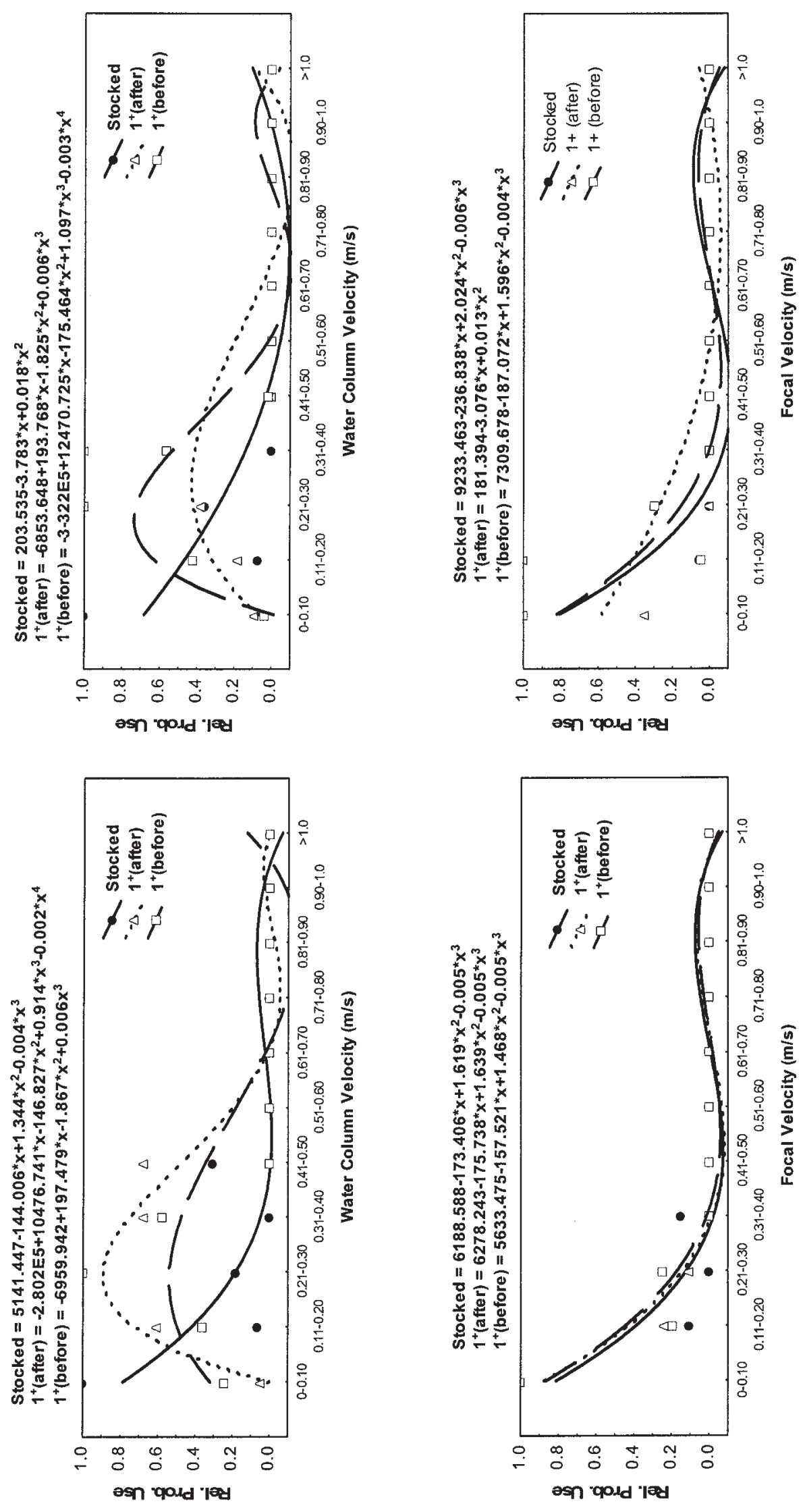
Additionally, the high vulnerability of stocked fish to predation (JACOBSEN, 2005), which is present in both streams, namely by otters (Lutra lutra), coupled with the possible decline of fish condition during their adaptation to habitat and available food resources may have been responsible for the decrease of stocked trout. Moreover, as summarized by WHITE et al. (1995), the morphological (deformities, hyperbuoyancy), physiological (stress response, pathogenic diseases) and behavioural characteristics (lack of social hierarchy, weak territorial behaviour) normally displayed by stocked trout could explain their potentially disadvantageous performance in relation to wild fish.

A very low relative contribution of the tested environmental variables in native trout distribution was found and $80 \%$ of the variance remained unexplained in the PCCA, suggesting that more habitat descriptors should be considered, although other factors can affect the trout distribution in streams, such as food availability, competition and predation (ORTH, 1987). The sampling technique used (underwater observation) can also be responsible for biased data, especially when conditions are less than ideal. For example, limited application is associated with deep areas, dark substrate, high presence of LWD, bad underwater visibility or the counting of organisms in dense populations (GRIFFITH et al., 1984; HEGGENES et al., 1990; THUROW and SCHILL, 1996). However, underwater observation is a valid technique to estimate abundance, size structure (WILDMAN and NEUMANN, 2002; JOYCE and HUBERT, 2003) and habitat use (FLEBBE and DOLLOFF, 1995; DOLLOFF et al., 1996). In the studied streams this technique was generally effective, although potential bias could be associated with the displacement of some fish in an upstream direction during the diver's progression. Additionally, under-estimates occur with the smaller native fish, which are more difficult to observe than stocked ones, and to the sampling of shallow riffles ( $<20 \mathrm{~cm}$ of total depth). However, most of the riffles had areas with enough depth to cover the mask and facilitate data collection.

Different microhabitat requirements were observed between stocked and native trout. In fact, the DFA analysis showed that focal elevation, total depth and cover were the most important microhabitat variables discriminating between stocked and native trout in both streams (Table II). Other surveys have found that these parameters and the distance to the nearest refuge were the variables that better explained the different behavioural patterns of native and non-native species (LARSON and MOORE, 1985; LOHR and WEST, 1992; MAGOULICK and WILZBACK, 1997). In this study, stocked trout remained in deeper pools, normally away from a definite refuge, with focal elevations far from the benthic zone, contrasting with native individuals who where usually near the streambed and shelter. Also, the released trout did not cause, apparently, the displacement of the resident trout from their usual habitat. Corroborating this assumption, non-parametric tests on microhabitat use, made before and after stocking, showed that there was no evidence of any change in niche characteristics of the native trout. The low impact of the stocked trout on resident populations is also confirmed by the lack of agonistic interactions assessed during snorkel surveys, despite the larger size and more aggressive behaviour normally displayed by stocked trout, as reported by MESA (1991) and DEVERILL et al. (1999). Thus, it is possible that the habitat segregation followed by native and stocked fish may be the result of selective segregation rather than competitive interactions (interactive segregation). Finally, the preference curves also reflected a difference in microhabitat use by stocked and native trout of the same age $\left(1^{+}\right)$, which had displayed a similar pattern before and after stocking (Fig. 2). Despite the presence of stocked fish, similar results were obtained by other investigators for juvenile native trout. For example, VISMARA et al. (2001) found optimum values for depth suitability curves at $90-100 \mathrm{~cm}$, which tally with those obtained in both streams, especially in the Sabor stream. Preference for water velocities $<0.20 \mathrm{~m}_{\mathrm{s}} \mathrm{s}^{-1}$ and coarse substrate habitats (mainly boulders) that provided cover were other characteristics shared by juvenile trout in both studies. Low focal (snout) velocity preference $(<0.10 \mathrm{~m}$. $\mathrm{s}^{-1}$ ) has also been reported by HEGGENES and SALTVEIT (1990) and HEGGENES (1996). However, a wide range of values for each microhabitat variable was found in the literature 
(BOVEE, 1978; BELAUD et al., 1989; ROUSSEL et al., 1999; ROUSSEL and BARDONNET, 2002). Several studies considering two life-stages (adult and juvenile brown trout) were compared (VISMARA et al., 2001) for experimental univariate Habitat Suitability Curves (HSC) and the differences obtained were explained essentially by the characteristics (e.g. habitat availability) of the investigated rivers. For this reason the development of site-specific HSC is often recommended and its transferability among distinct systems questioned by its feasibility (HEGGENES and SALTVEIT, 1990; GREENBERG et al., 1996). Furthermore, it has been argued that HSC must be developed for each species taking into account the developmental stages (alevins, juveniles, adults), seasonal (summer vs. winter) and day cycles (night vs. day) and the main activities exhibited by fish (i.e. feeding or resting) (ROUSSEL et al., 1999; HEGGENES and DOKK, 2001).

In conclusion it is evident that stocking is far from being an adequate technique for management since the released trout do not contribute to sustainable populations because of a reduced adaptation to the in-stream environment, in spite of their low intrusion into the habitat of the wild population. However, complementary surveys are needed to find strong evidence for competition, namely through controlled experiments with substitutive designs, in order to quantify the ecological effects of stocked trout on the rehabilitation of native populations (WEBER and FAUSCH, 2003). More attention must also be paid to the genetic impact on native trout populations of supplemental stocking programs. However, there is a low introgression rate in the streams of this region (ANTUNES, 2001; SANTOS, 2004), a consequence of the lower performances of hatchery stocks in wild environments. Therefore a proper understanding of the ecological processes regulating each aquatic system is essential in order to define the best management strategies of trout populations. Such identification of the potential impact of stocked fish on native populations implicates to develop alternative management strategies in the Portuguese salmonid streams, specifically enhancement practices to improve habitat quality.

\section{ACKNOWLEDGEMENTS}

This research was supported by the Direcção Geral de Recursos Florestais. Special thanks to the director of the Fisheries Division, Jorge Bochechas, who made possible this collaboration, and to Rogério Rodrigues and Julieta Sampaio from the Direcção Regional de Agricultura de Trás-os-Montes who made available the fishfarms of this organization. Audrey Gerry provided helpful suggestions, which led to the linguistic improvements of this manuscript.

\section{REFERENCES}

ALMODÓVAR A., SUÁREZ J., NICOLA G.G., NUEVO M., 2001. Genetic introgression between wild and stocked brown trout Salmo trutta in the Douro River Basin, Spain. J. Fish Biol., 59, 68-74.

ANTUNES A., FARIA R., WEISS S., ALEXANDRINO P., 2001. Complex evolutionary history in the brown trout: Insights on the recognition of conservation units. Conservation Genetics, 2, 337-347.

APRAHAMIAN M.W., MARTIN SMITH K., McGINNITY P., McKELVEY S., TAYLOR, J., 2003. Restocking of salmonids - Opportunities and limitations. Fish. Res., 62, 211-227.

BALTZ D., VONDRACEK B., BROWN L., MOYLE P., 1991. Seasonal changes in microhabitat selection by rainbow trout in a small stream. T. Am. Fish. Soc., 120, 166-176.

BELAUD A., CHAVEROCHE P., LIM P., SABATON C., 1989. Probability-of-use curves applied to brown trout (Salmo trutta fario L.) in rivers of Southern France. Regulated Rivers, 3, 321-326. 
BISSON P.A., NIELSEN R.A., PALMASON R.A., GROVE L.E., 1982. A system-naming habitat types in small streams, with examples of habitat utilization by salmonids during low streamflow. In: ARMANTROUT N.B. (ed.), Acquisition and Utilization of Aquatic Inventory Information, 62-73, Symposium Proceedings, Portland, Oregon.

BLANCO G., CAGIGAS E., VÁSQUEZ E., SÁNCHEZ J.A., 1998. Genetic impact of introduced domesticated strains of brown trout, Salmo trutta, on native Spanish populations. In: COWX, I.G. (ed.), Stocking and Introduction of Fish, 371-379, Fishing News Books, Blackwell Science, Oxford.

BOVEE K.D., 1978. Probability-of-use criteria for the family Salmonidae. Instream Flow Information Paper 4, U. S. Fish and Wildlife Service (FWS/OBS-78/07).

BOVEE K.D., 1982. A guide to stream habitat analysis using the Instream Flow Incremental Methodology. Office of Biological Sciences, U.S. Fish and Wildlife Service (FWS/ OBS-82/26).

BOVEE K.D., MILHOUS R.T., 1978. Hydraulic Simulation in instream flow studies: theory and technique. U.S. Fish and Wildlife Service (FWS/OBS-78/33).

CAGIGAS M.E., VÁSQUEZ E., BLANCO G., SUÁREZ J., 1999. Genetic effects of introduced hatchery stocks on indigenous brown trout (Salmo trutta L.) populations in Spain. Ecol. Freshw. Fish, 8, 141-150.

CORTES R., TEIXEIRA A., PEREIRA C., 1996. Is supplemental stocking of brown trout (Salmo trutta) worthwhile in low productive streams? Folia Zool., 45, 371-381.

COWX I.G., 1998. Stocking strategies: issues and options for future enhancement programs. In: COWX I.G. (ed.), Stocking and Introduction of Fish, 3-13, Fishing News Books, Blackwell Science, Oxford.

CRESSWELL R., 1981. Post-stocking movements and recapture of hatchery-reared trout into flowing waters - a review. J. Fish Biol., 18, 429-441.

DEVERILL J.E., ADAMS C.E., BEAN C.W., 1999. Prior residence, aggression and territory acquisition in hatchery-reared and wild brown trout. J. Fish Biol., 55, 868-875.

DOLLOFF C.A., KERSHNER J., THUROW R., 1996. Underwater observations. In: MURPHY B.R., WILLIS D.W. (eds.), Fisheries Techniques, 533-554, American Fisheries Society, Bethesda, Maryland.

EVEREST F.H., CHAPMAN D.W., 1972. Habitat selection and spatial interactions of juvenile Chinook salmon and steelhead trout in two Idaho streams. Journal of the Fisheries Research Board of Canada, 19, 91-100.

FAUSCH K.D., 1984. Profitable stream positions for salmonids: relating specific growth rate to net energy gain. Can. J. Zool., 62, 441-451.

FAUSCH K.D., 1988. Tests of competition between native and introduced salmonids in streams: what have we learned? Can. J. Fish. Aquat. Sci., 45, 2238-2246.

FLEBBE P.A., DOLLOFF C.A., 1995. Trout use of woody debris and habitat in Appalachian wilderness streams of North Carolina. N. Am. J. Fish. Manage., 15, 579-590.

GARCÍA-MARIN J., SANZ N., PLA C., 1999. Erosion of the native genetic resources of brown trout in Spain. Ecol. Freshw. Fish, 8, 151-158.

GREENBERG L., SVENDSEN P., HARBY A., 1996. Availability of microhabitats and their use by brown trout (Salmo trutta) and grayling (Thymallus thymallus) in the River Vojman, Sweden. Regul. Rivers: Res. Mgmt., 12, 287-303. 
GRIFFITH J.S., SCHILL D.J., GRESSWELL R.E., 1984. Underwater observations as a technique for assessing fish abundance in large western rivers. Proceedings of the Annual Conference Western Association of Fish and Wildlife Agencies. 63, 143149.

HEGGENES J., 1988. Effects of short-term flow fluctuations on displacement of, and habitat use by, brown trout in a small stream. T. Am. Fish. Soc., 117, 336-344.

HEGGENES J., 1996. Habitat selection by brown trout (Salmo trutta) and young Atlantic salmon (Salmo salar) in streams: static and dynamic hydraulic modelling. Regul. Rivers: Res. Mgmt., 12, 155-169.

HEGGENES J., BRABRAND A., SALTVEIT S.J., 1990. Comparison of three methods for studies of stream habitat use by young brown trout and Atlantic salmon. T. Am. Fish. Soc., 119, 101-111.

HEGGENES J., DOKK J.G., 2001. Contrasting temperatures, waterflows, and light: seasonal habitat selection by young Atlantic salmon and brown trout in a boreonemoral river. Regul. Rivers: Res. Mgmt., 17, 623-635.

HEGGENES J., SALTVEIT S.J., 1990. Seasonal and spatial microhabitat selection and segregation in young Atlantic salmon, Salmo salar L., and brown trout, Salmo trutta L. in a Norwegian River. J. Fish Biol., 36, 707-720.

HUGHES N.F., DILL L.M., 1990. Position choice of drift-feeding salmonids: model and test for Arctic grayling (Thymallus arcticus) in subarctic mountain streams, interior Alaska. Can. J. Fish. Aquat. Sci., 47, 2039-2048.

JACOBSEN L., 2005. Otter (Lutra lutra) predation on stocked trout (Salmo trutta) in two Danish lowland rivers. Ecol. Freshw. Fish, 14, 59-68.

JONSSON S., BRANNAS E., LUNDQVIST H., 1999. Stocking of brown trout, Salmo trutta L. Effects of acclimatization. Fish. Manage. Ecol., 6, 459-473.

JOYCE M.P., HUBERT W.A., 2003. Snorkelling as an alternative to depletion electrofishing for assessing Cutthroat trout and brown trout in stream pools. J. Freshw. Ecol., 18(2), 215-222.

LARSON G.L., MOORE S.E., 1985. Encroachment of exotic rainbow trout into stream populations of native brook trout in the southern Appalachian Mountains. T. Am. Fish. Soc., 114, 195-203.

LOHR S., WEST J., 1992. Microhabitat selection by brook and rainbow trout in a Southern Appalachian River. T. Am. Fish. Soc., 121, 729-736.

MACHORDOM A., SUÁREZ J., ALMODÓVAR A., BAUTISTA J.M., 2000. Genetic differentiation and phylogenetic relationships among Spanish brown trout (Salmo trutta) populations. Mol. Ecol., 9, 1325-1338.

MAGOULICK D., WILZBACH M., 1997. Microhabitat selection by native brook trout and introduced rainbow trout in a small Pennsylvania stream. J. Freshwater Ecol., 12, 607-614.

McMICHAEL G.A., PEARSONS T.N., 1997. Effects of residual hatchery-reared steelhead on growth of wild rainbow trout and spring chinook salmon. T. Am. Fish. Soc., 126, 230-239.

McMICHAEL G.A., PEARSONS T.N., LEIDER S.A., 1999. Behavioral interactions among hatchery-reared steelhead smolts and wild Onchorhynchus mykiss in natural streams. N. Am. J. Fish. Manage., 19, 948-956. 
MESA M.G., 1991. Variation in feeding, aggression and position choice between hatchery and wild cutthroat trout in an artificial stream. T. Am. Fish. Soc., 120, 723-727.

MOFFIT C.M., STEWART B.C., LAPATRA S.E., BRUNSON R.D., BARTHOLOMEW J.L., PETERSON J.E., AMOS K.H., 1998. Pathogens and diseases of the fish in aquatic ecosystems: implications for fisheries and management. J. Aquat. Anim. Health, 10, 95-100.

MORING J.R., 1993. Records of long-range, downstream movements of stocked rainbow trout (Oncorhynchus mykiss). Fish. Res., 16, 195-199.

NASLUND I., 1998. Survival and dispersal of hatchery-reared brown trout, Salmo trutta, released in small streams. In: COWX, I.G. (ed.), Stocking and Introduction of Fish, 59-76, Fishing News Books, Blackwell Science, Oxford.

NEHLSEN W., WILLIAMS J.E., LICHATOWICH J.A., 1991. Pacific salmon at the crossroads: stocks at risk from California, Oregon, Idaho, and Washington. Fisheries, 16, 4-21.

NICKELSON T.E., SOLAZZI M.F., JOHNSON S.L., 1986. Use of hatchery coho salmon (Onchorhynchus kisutch) presmolts to rebuild wild populations in Oregon coastal streams. Can. J. Fish. Aquat. Sci., 43, 2443-2449.

ORTH D.J., 1987. Ecological consideration in the development and application of instream flow-habitat models. Regul. Rivers: Res. Mgmt., 1, 171-181.

PEERY C.A., BJORNN T.C., 2000. Dispersal of hatchery-reared Chinook salmon parr following release into four Idaho streams. N. Am. J. Fish. Manage., 20, 19-27.

ROUSSEL J.M., BARDONNET A., CLAUDE A., 1999. Microhabitats of brown trout when feeding on drift and when resting in a lowland salmonid brook: effects on Weighted Usable Area. Arch. Hydrobiol., 146, 413-429.

ROUSSEL J.M., BARDONNET A. 2002. Habitat de la truite commune (Salmo trutta L.) pendant la période juvénile en ruisseau: préférences, mouvements, variations journalières et saisonnières. Bull. Fr. Pêche Piscic., 365/366, 435-454.

SANTOS N.P., 2004. Efeito dos repovoamentos na conservação genética da truta (Salmo trutta L.). Master Thesis. Universidade de Trás-os-Montes e Alto Douro. Vila Real, $108 \mathrm{p}$.

SANZ N., GARCÍA-MARIN J., PLA, C., 2000. Divergence of brown trout (Salmo trutta) within glacial refugia. Can. J. Fish. Aquat. Sci., 57, 2201-2210.

STATSOFT. Inc. 2004. STATISTICA (Data Analysis Software System). Version 7. www. statsoft.com. Tulsa, USA.

SUÁREZ J. BAUTISTA J.M., ALMODÓVAR A., MACHORDOM A., 2001. Evolution of the mitochondrial control region in Paleartic brown trout (Salmo trutta) populations: the biogeographical role of the Iberian Peninsula. Heredity, 87, 198-206.

TER BRAAK C.J.F., SMILAUER P., 1998. CANOCO. Reference manual and user's guide to Canoco for Windows: Software for Canonical Community Ordination (version 4). Microcomputer Power, Ithaca, NY, USA.

THUROW R.F., SCHILL D.J., 1996. Comparison of day snorkelling, night snorkelling, and electrofishing to estimate bull trout abundance and size structure in a second-order Idaho stream. N. Am. J. Fish. Manage., 16, 314-323.

VISMARA R., AZZELLINO A., BOSI R., CROSA G., GENTILI G., 2001. Habitat suitability curves for brown trout (Salmo trutta fario L.) in the river Arda, Northern Italy: Comparing univariate and multivariate approaches. Regul. Rivers: Res. Mgmt., 17, 37-50. 
WEBER E.D., FAUSCH K.D., 2003. Interactions between hatchery and wild salmonids in streams: differences in biology and evidence for competition. Can. J. Fish. Aquat. Sci., 60, 1018-1036.

WELCOMME R.L., 1998. Evaluation of stocking and introductions as management tools. In COWX, I.G. (ed.), Stocking and Introduction of Fish, 397-413, Fishing News Books, Blackwell Science, Oxford.

WHITE R.J., KARR J.R., NEHLSEN W., 1995. Better roles for fish stocking in aquatic resource management. In: SCHRAMM H.L. Jr., PIPER, R.G. (eds.), Uses and Effects of Cultured Fish in Aquatic Ecosystems, 527-547, American Fisheries Society, Bethesda, Maryland.

WILDMAN T.L., NEUMANN R.M., 2002. Comparison of snorkelling and electrofishing for estimating abundance and size structure of brook trout and brown trout in two southern New England streams. Fish. Res., 1405, 1-9. 